\title{
Alkaloids with Cardiovascular Effects from the Marine-Derived Fungus Penicillium expansum Y32
}

\section{Ya-Qin Fan ${ }^{1, \dagger}$, Pei-Hai Li ${ }^{1, \dagger}$, Ya-Xi Chao ${ }^{1}$, Hao Chen ${ }^{1, *}$, Ning Du ${ }^{1}$, Qiu-Xia He ${ }^{2}$ and Ke-Chun Liu ${ }^{2}$}

1 Key Lab of Marine Bioactive Substances, First Institute of Oceanography, State Oceanic Administration, Qingdao 266061, China; E-Mails: fanyaqin.826@163.com (Y.-Q.F.); lipeihaihg@sina.com (P.-H.L.); yaxichao@163.com (Y.-X.C.); duning@fio.org.cn (N.D.)

2 Institute of Biology, Shandong Academy of Sciences; Research and Development Platform for Drug Screening of Shandong Academy of Sciences, Jinan 250014, China;

E-Mails: heqiuxia8008@163.com (Q.-X.H.); hliukch@keylab.net (K.-C.L.)

$\dagger$ These authors contributed equally to this work.

* Author to whom correspondence should be addressed; E-Mail: hchen@fio.org.cn; Tel./Fax: +86-532-8896-3855.

Academic Editor: Orazio Taglialatela-Scafati

Received: 22 August 2015 / Accepted: 9 October 2015 / Published: 22 October 2015

\begin{abstract}
Three new alkaloids (1, 4 and 8), together with nine known analogues (2, 3, 5-7, and 9-12), were isolated from the marine-derived fungus Penicillium expansum Y32. Their structures including the absolute configurations were elucidated by spectroscopic and Mosher's and Marfey's methods, along with quantum electronic circular dichroism (ECD) calculations. Each of the compounds was evaluated for cardiovascular effects in a live zebrafish model. All of the compounds showed a significant mitigative effect on bradycardia caused by astemizole (ASM) in the heart rate experiments. Compounds 4-6 and 8-12 exhibited potent vasculogenetic activity in vasculogenesis experiments. This is the first study to report that these types of compounds show cardiovascular effects in zebrafish. The results suggest that these compounds could be promising candidates for cardiovascular disease lead compounds.
\end{abstract}

Keywords: marine-derived fungus; Penicillium expansum; secondary metabolites; alkaloids; cardiovascular effects 


\section{Introduction}

According to the World Health Organization, cardiovascular diseases (CVDs) are the number one cause of death globally: more people die annually from CVDs than from any other cause. In 2012, 17.5 million people, representing $31 \%$ of all global deaths, died from this disease. CVDs are disorders of the heart and blood vessels and include coronary heart disease, cerebrovascular disease, peripheral arterial disease, rheumatic heart disease, congenital heart disease and other conditions [1]. Unfortunately, the number of people suffering from CVDs is on the rise, but only few and expensive drugs are available to treat the diseases. It is of great significance to search new and effective drugs to combat CVDs. In order to discover related lead compounds from marine-derived fungi, a fungus Penicillium expansum Y32 has been isolated from a seawater sample collected from the Indian Ocean. A chemical investigation of the ethyl acetate extract of fermentation broth of Y32 led to the identification of three new alkaloids, named communesin I (1), fumiquinazoline Q (4) and protuboxepin E (8), along with nine known analogues, communesin A and B (2 and 3) [2-4], cottoquinazoline A (5) [5], prelapatin B (6), glyantrypine (7) [6], protuboxepin A and B (9 and 10) [7], chaetoglobosin C (11) [8] and penochalasin E (12) [9] (Figure 1).

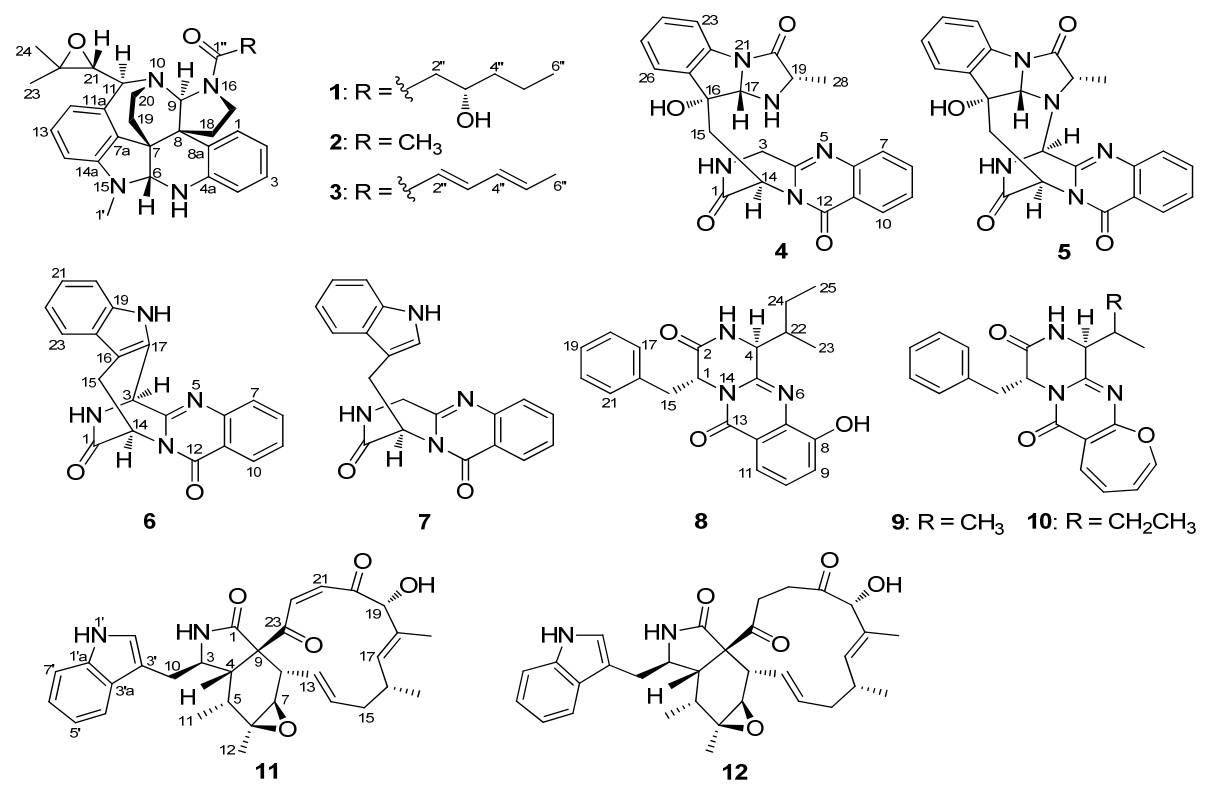

Figure 1. Structures of Compounds 1-12.

Compounds 1-12 were screened for cardiovascular effects in a model of live zebrafish, which provides a system for drug screening that combines the biological complexity of in vivo models with the ability for much higher throughput screening than other available animal models [10]. In the heart rate experiments, all of the compounds showed significant mitigative effects on bradycardia caused by astemizole (ASM) at different concentrations. In the vasculogenesis experiments, Compounds 4-6 and 8-12 (at concentrations of $20 \mu \mathrm{g} / \mathrm{mL}, 50 \mu \mathrm{g} / \mathrm{mL}$ and $100 \mu \mathrm{g} / \mathrm{mL}$ ) exhibited potent vasculogenetic activity regarding vessel numbers, and four hits $(4,6,8$ and 10) displayed remarkable promoting functions regarding vessel length. Additionally, 12 compounds were also evaluated in antiangiogenic experiments, and no obvious activity was observed (the results are not listed). The results indicated that these compounds might be used for screening for new natural cardiovascular effect candidates. 


\section{Results and Discussion}

Communesin I (1) was obtained as a white amorphous powder. The molecular formula was determined to be $\mathrm{C}_{32} \mathrm{H}_{40} \mathrm{~N}_{4} \mathrm{O}_{3}$ using high-resolution electrospray ionisation mass spectrometry (HRESIMS) with a peak at $m / z 529.3184[\mathrm{M}+\mathrm{H}]^{+}$, indicating 15 degrees of unsaturation. The UV spectrum of 1 showed identical absorptions with communesin analogues at 206, 248, 268 and $320 \mathrm{~nm}$ [3]. The observed signals in ${ }^{1} \mathrm{H}$ nuclear magnetic resonance (NMR), ${ }^{13} \mathrm{C}$ NMR and DEPT spectra of 1 (Table 1) for twelve aromatic carbons (seven methines and five quaternary carbons) with seven protons (three triplets and four doublets) were indicative of a ortho-disubstituted benzene ring system and a 1,2,3-trisubstituted benzene system. Those deductions were further verified by the key correlation spectroscopy (COSY) correlations of $\mathrm{H}-1\left(\delta_{\mathrm{H}} 6.68, \mathrm{~d}, J=7.6 \mathrm{~Hz}\right) / \mathrm{H}-2\left(\delta_{\mathrm{H}} 6.71\right.$, $\mathrm{t}, J=7.6 \mathrm{~Hz}) / \mathrm{H}-3\left(\delta_{\mathrm{H}} 7.01, \mathrm{t}, J=7.6 \mathrm{~Hz}\right) / \mathrm{H}-4\left(\delta_{\mathrm{H}} 6.69, \mathrm{~d}, J=7.6 \mathrm{~Hz}\right)$ and $\mathrm{H}-12\left(\delta_{\mathrm{H}} 6.05\right.$, $\mathrm{d}, J=7.7 \mathrm{~Hz}) / \mathrm{H}-13\left(\delta_{\mathrm{H}} 6.88, \mathrm{t}, J=7.7 \mathrm{~Hz}\right) / \mathrm{H}-14\left(\delta_{\mathrm{H}} 5.95, \mathrm{~d}, J=7.7 \mathrm{~Hz}\right)$ along with the heteronuclear multiple-bond correlation spectroscopy (HMBC) correlations from $\mathrm{H}-1$ and $\mathrm{H}-3$ to the quaternary carbon $\mathrm{C}-4 \mathrm{a}\left(\delta_{\mathrm{C}} 142.6\right)$, from $\mathrm{H}-2$ and $\mathrm{H}-4$ to the quaternary carbon $\mathrm{C}-8 \mathrm{a}\left(\delta_{\mathrm{C}} 132.1\right)$, from $\mathrm{H}-12$ and $\mathrm{H}-14$ to the quaternary carbon $\mathrm{C}-7 \mathrm{a}(\delta \mathrm{c} 132.1)$ and from $\mathrm{H}-13$ to two quaternary carbons $(\mathrm{C}-11 \mathrm{a}$, $\left.\delta_{\mathrm{C}} 136.1 ; \mathrm{C}-14 \mathrm{a}, \delta_{\mathrm{c}} 150.5\right)$. The resonances at $\delta_{\mathrm{c}} 29.6(\mathrm{qC})$ and $\delta_{\mathrm{H}} 2.84(3 \mathrm{H}, \mathrm{s})$ indicated the presence of an $\mathrm{N}$-methyl group. In addition, three methyls, seven methylenes, five methines and four quaternary carbons appeared in the ${ }^{1} \mathrm{H}$ NMR, ${ }^{13} \mathrm{C}$ NMR, and DEPT spectra. Combined with the COSY spectrum, two $-\mathrm{CH}_{2}-\mathrm{CH}_{2}-$ spin systems, one 2,2-dimethyloxirane group and one pentan-2-ol moiety were deduced (Figure 2). Extensive comparison of the ${ }^{1} \mathrm{H}$ and ${ }^{13} \mathrm{C}$ NMR spectra with those of communesin A (2) revealed that the structures of these two compounds were very similar, except for the fact that the signals of the methyl group (C-2") in communesin A were replaced by the pentan-2-ol moiety in $\mathbf{1}$. The assignment was confirmed by the HMBC correlations from H-6 ( $\delta 4.70)$ to C-4a $(\delta 142.6)$, $\mathrm{C}-7 \mathrm{a}\left(\delta\right.$ 132.1), $\mathrm{C}-8\left(\delta\right.$ 52.1) and $\mathrm{C}-14 \mathrm{a}\left(\delta\right.$ 150.5), from $\mathrm{H}_{3}-1^{\prime}(\delta 2.84)$ to $\mathrm{C}-6(\delta$ 82.4) and

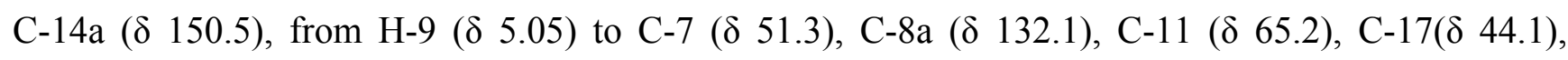
C-18 $(\delta 30.6)$ and C-20 ( $\delta 36.1)$, from H-11 ( $\delta 4.11)$ to C-7a $(\delta 132.1)$, C-9 $(\delta 79.1), \mathrm{C}-12(\delta 113.1)$ and $\mathrm{C}-20$, from $\mathrm{H}_{\mathrm{b}}-17(\delta 3.00)$ to $\mathrm{C}-1 "$ " $\left(\delta\right.$ 173.9), from $\mathrm{H}_{2}-18(\delta 2.71 / 2.00)$ to $\mathrm{C}-7(\delta 51.3)$ and C-8a $(\delta 132.1)$, from $\mathrm{H}_{2}-19(\delta 2.37 / 2.28)$ to $\mathrm{C}-6(\delta 82.4), \mathrm{C}-7 \mathrm{a}(\delta 132.1)$ and $\mathrm{C}-8(\delta 52.1)$, and from $\mathrm{H}_{2}-2 "(\delta 2.82 / 2.48)$ to $\mathrm{C}-1 "$ " $(\delta$ 173.9) (Figure 2$)$. Therefore, the planar structure of communesin I (1) was established.

The relative configuration was determined by nuclear Overhauser effect spectroscopy (NOESY) experiments and Murata's $J$-based method [3,11]. The NOESY correlations of H-1/H-9 $\left(\delta_{\mathrm{H}} 5.05\right) / \mathrm{H}-11$ $\left(\delta_{\mathrm{H}} 4.11\right) / \mathrm{H}-12\left(\delta_{\mathrm{H}} 6.05\right), \mathrm{H}_{3}-1^{\prime} \quad\left(\delta_{\mathrm{H}} \quad 2.84\right) / \mathrm{H}-6 \quad\left(\delta_{\mathrm{H}} \quad 4.70\right) / \mathrm{H}_{2}-19 \quad(\delta \quad 2.37 / 2.28)$, and $\mathrm{H}_{\mathrm{a}-19}$ $\left(\delta_{\mathrm{H}} 2.37\right) / \mathrm{H}_{\mathrm{a}}-18\left(\delta_{\mathrm{H}} 2.71\right)$ confirmed the two $-\mathrm{CH}_{2}-\mathrm{CH}_{2}-$ bridges, $\mathrm{H}-6$ and $\mathrm{H}_{3}-1$ ", to be on the same side, which displayed a similar correlative pattern to those of 2 (Figure 3). Application of Murata's

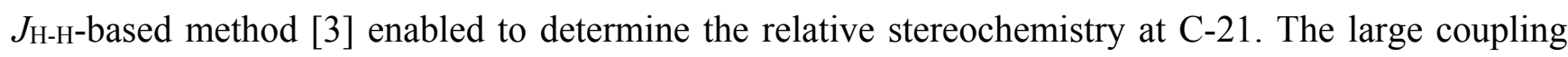
constant between $\mathrm{H}-21$ and $\mathrm{H}-11\left(\mathrm{~J}_{\mathrm{H}-\mathrm{H}}=9 \mathrm{~Hz}\right)$ indicated an approximate $180^{\circ}$ (anti arrangement) of

the dihedral angles of H11-C11-C21-H21 (Figure 4). Additionally, the NOE correlations of $\mathrm{H}_{3}-23 / \mathrm{H}_{3}-24 / \mathrm{H}-12$ and the absent correlations of the geminal methyl groups to $\mathrm{H}-9$ or $\mathrm{H}_{2}-19 / 20$ supported the theory that the epoxide oxygen was oriented syn to $N-10$ as shown in conformation A in Figure 4. 
Table 1. ${ }^{1} \mathrm{H}$ and ${ }^{13} \mathrm{C}$ nuclear magnetic resonance (NMR) data of Compounds $\mathbf{1}$ and $\mathbf{8}$.

\begin{tabular}{|c|c|c|c|c|c|}
\hline \multicolumn{3}{|c|}{$1^{a}$} & \multicolumn{3}{|r|}{$8^{b}$} \\
\hline Position & $\boldsymbol{\delta}_{\mathbf{C}}$ & $\delta_{\mathrm{H}}$, Mult. $(J$ in $\mathrm{Hz})$ & Position & $\boldsymbol{\delta}_{\mathbf{C}}$ & $\delta_{\mathrm{H}}$, Mult. $(J$ in $\mathrm{Hz})$ \\
\hline 1 & $123.2, \mathrm{CH}$ & $6.68, \mathrm{~d}(7.6)$ & 1 & $56.5, \mathrm{CH}$ & $5.29, \mathrm{t}(5.0)$ \\
\hline 2 & $120.6, \mathrm{CH}$ & $6.71, \mathrm{t}(7.6)$ & 2 & $167.4, \mathrm{C}$ & \\
\hline 3 & $127.5, \mathrm{CH}$ & 7.01, t (7.6) & 3 & & 8.32, brs \\
\hline 4 & 117.0, $\mathrm{CH}$ & $6.69, \mathrm{~d}(7.6)$ & 4 & $57.8, \mathrm{CH}$ & $3.19, \mathrm{~d}(1.7)$ \\
\hline $4 a$ & 142.6, C & & 5 & $149.1, \mathrm{C}$ & \\
\hline 6 & $82.4, \mathrm{CH}$ & $4.70, \mathrm{~s}$ & 7 & $135.7, \mathrm{C}$ & \\
\hline 7 & $51.3, \mathrm{C}$ & & 8 & $152.6, \mathrm{C}$ & \\
\hline $7 \mathrm{a}$ & $132.1, \mathrm{C}$ & & 9 & $118.7, \mathrm{CH}$ & $7.25, \mathrm{~d}(7.9)$ \\
\hline 8 & $52.1, \mathrm{C}$ & & 10 & 127.3, $\mathrm{CH}$ & $7.37, \mathrm{t}(7.9)$ \\
\hline $8 a$ & 132.1, C & & 11 & $116.0, \mathrm{CH}$ & 7.59, d (7.9) \\
\hline 9 & $79.1, \mathrm{CH}$ & $5.05, \mathrm{~s}$ & 12 & $120.5, \mathrm{C}$ & \\
\hline 11 & $65.2, \mathrm{CH}$ & $4.11, \mathrm{~d}(9.0)$ & 13 & $160.0, \mathrm{C}$ & \\
\hline $11 \mathrm{a}$ & 136.1, C & & 15 & $36.4, \mathrm{CH}_{2}$ & $3.27, \mathrm{dd}(9.2,5.0) 3.32^{\mathrm{c}}, \mathrm{m}$ \\
\hline 12 & $113.1, \mathrm{CH}$ & $6.05, \mathrm{~d}(7.7)$ & 16 & $135.4, \mathrm{C}$ & \\
\hline 13 & $129.0, \mathrm{CH}$ & $6.88, \mathrm{t}(7.7)$ & 17 & $129.5, \mathrm{CH}$ & $6.92, \mathrm{~d}(7.0)$ \\
\hline 14 & $101.9, \mathrm{CH}$ & $5.95, \mathrm{~d}(7.7)$ & 18 & $128.5, \mathrm{CH}$ & $7.20, \mathrm{t}(7.0)$ \\
\hline $14 \mathrm{a}$ & $150.5, \mathrm{C}$ & & 19 & $127.5, \mathrm{CH}$ & $7.24, \mathrm{~m}$ \\
\hline $\begin{array}{l}17 \mathrm{a} \\
17 \mathrm{~b}\end{array}$ & $44.1, \mathrm{CH}_{2}$ & $\begin{array}{c}3.92, \mathrm{dd}(12.2,8.7) \\
3.00, \mathrm{dt}(12.2,7.1)\end{array}$ & 20 & $128.5, \mathrm{CH}$ & $7.20, \mathrm{t}(7.0)$ \\
\hline $\begin{array}{l}18 \mathrm{a} \\
18 \mathrm{~b}\end{array}$ & $30.6, \mathrm{CH}_{2}$ & $\begin{array}{l}2.71, \mathrm{dt}(12.2,8.7) \\
2.00, \mathrm{dd}(12.2,7.1)\end{array}$ & 21 & $129.5, \mathrm{CH}$ & $6.92, \mathrm{~d}(7.0)$ \\
\hline $\begin{array}{l}19 a \\
19 b\end{array}$ & $37.7, \mathrm{CH}_{2}$ & $\begin{array}{c}2.37, \mathrm{dd}(12.8,8.5) \\
2.28, \mathrm{dt}(12.8,9.5)\end{array}$ & 22 & $35.0, \mathrm{CH}$ & $2.69, \mathrm{~m}$ \\
\hline $\begin{array}{l}20 \mathrm{a} \\
20 \mathrm{~b}\end{array}$ & $36.1, \mathrm{CH}_{2}$ & $\begin{array}{c}3.46, \mathrm{dd}(15.8,9.5) \\
3.36, \mathrm{dt}(15.8,8.5)\end{array}$ & 23 & $15.4, \mathrm{CH}_{3}$ & $0.91, \mathrm{~d}(7.3)$ \\
\hline 21 & $64.1, \mathrm{CH}$ & $2.87, \mathrm{~d}(9.0)$ & 24 & $22.8, \mathrm{CH}_{2}$ & $1.17, \mathrm{~m}$ \\
\hline 22 & $60.4, \mathrm{C}$ & & 25 & $12.2, \mathrm{CH}_{3}$ & $0.73, \mathrm{t}(7.4)$ \\
\hline 23 & $24.9, \mathrm{CH}_{3}$ & $1.39, \mathrm{~s}$ & $8-\mathrm{OH}$ & & $9.50, \mathrm{~s}$ \\
\hline 24 & $20.3, \mathrm{CH}_{3}$ & $1.57, \mathrm{~s}$ & & & \\
\hline $1^{\prime}$ & $29.6, \mathrm{CH}_{3}$ & $2.84, \mathrm{~s}$ & & & \\
\hline $1^{\prime \prime}$ & 173.9, C & & & & \\
\hline $2^{\prime \prime}$ & $42.1, \mathrm{CH}_{2}$ & $\begin{array}{l}\text { 2.82, dd }(14.6,3.4) \\
2.48, \text { dd }(14.6,3.4)\end{array}$ & & & \\
\hline $3 "$ & $69.0, \mathrm{CH}$ & 4.06, brs & & & \\
\hline $4^{\prime \prime}$ & $39.5, \mathrm{CH}_{2}$ & $1.60, \mathrm{~m} ; 1.53, \mathrm{~m}$ & & & \\
\hline $5^{\prime \prime}$ & $18.9, \mathrm{CH}_{2}$ & $1.54, \mathrm{~m} ; 1.44, \mathrm{~m}$ & & & \\
\hline $6^{\prime \prime}$ & $14.1, \mathrm{CH}_{3}$ & $0.96, \mathrm{t}(7.0)$ & & & \\
\hline $\mathrm{OH}$ & & 4.14, brs & & & \\
\hline
\end{tabular}

${ }^{\mathrm{a}}$ Measured in $\mathrm{CDCl}_{3}\left({ }^{1} \mathrm{H} 600 \mathrm{MHz},{ }^{13} \mathrm{C} 150 \mathrm{MHz}, \mathrm{TMS}, \delta \mathrm{ppm}\right) ;{ }^{\mathrm{b}}$ Measured in DMSO- $d_{6}\left({ }^{1} \mathrm{H} 600 \mathrm{MHz}\right.$,

${ }^{13} \mathrm{C} 150 \mathrm{MHz}$, TMS, $\delta$ ppm); ${ }^{\mathrm{c}}$ Overlapped with $\mathrm{H}_{2} \mathrm{O}$ signal in DMSO- $d_{6}$. 

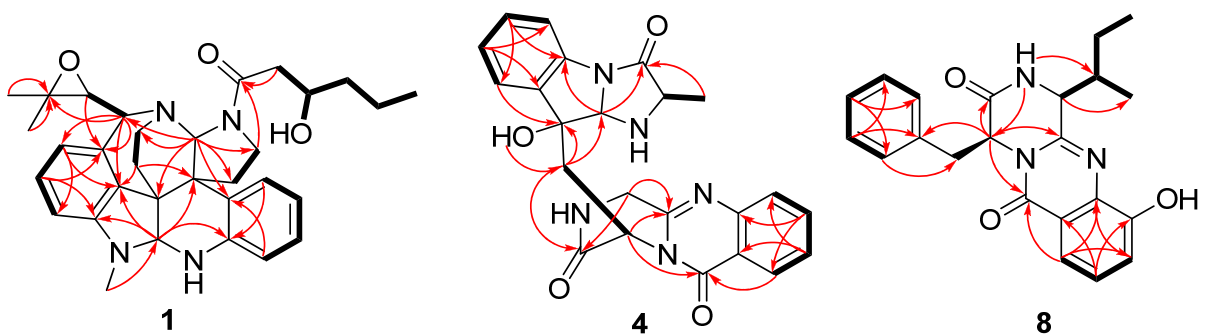

HMBC:

cosY: -

Figure 2. Key heteronuclear multiple-bond correlation spectroscopy (HMBC) and correlation spectroscopy (COSY) correlations of $\mathbf{1 , 4}$ and $\mathbf{8}$.
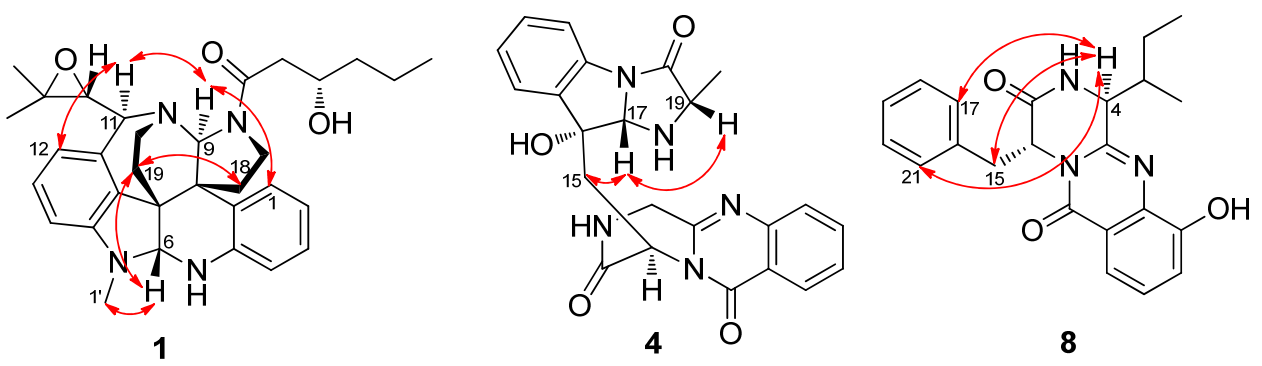

NOESY:

Figure 3. Key nuclear Overhauser effect spectroscopy (NOESY) correlations of 1, 4 and 8.

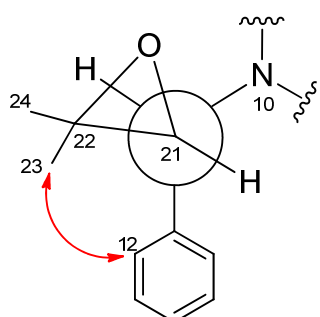

A

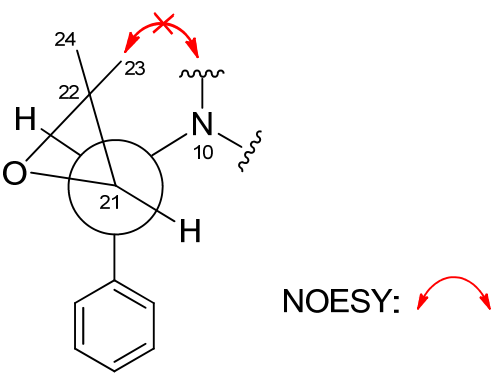

B

Figure 4. Stereochemistry of C-21 and C-11 in Compound $1\left(J_{21,11}=9.0 \mathrm{~Hz}\right.$, large $)$.

Compound 1 displayed a similar CD Cotton effect (Figure 5) to those of communesin A (2) and B (3) (Figure 5), absolute configurations of which have been reported in the previous literature [4], indicating the same $6 R, 7 R, 8 R, 9 S, 11 S$ and $21 R$ configurations. This was further confirmed by quantum chemical equivalent circulating density (ECD) calculation of $\mathbf{1}$ and ent-1 using Gaussian 09 (Figure 5) [12]. The preliminary conformational distribution search was performed using the HyperChem 7.5 software. The corresponding minimum geometries were further fully optimized using the density functional theory (DFT) at the B3LYP/6-31G(d) level as implemented in the Gaussian 09 program package [12]. The stable conformers obtained were submitted to ECD calculation using the time-dependent DFT (TDDFT) method (B3LYP/6-31G(d)). The overall predicted ECD spectrum of 1 was subsequently compared with the measured one. Finally, the measured CD curve matched well with the calculated curve for 1 and was opposite to that of ent-1 (Figure 5). 

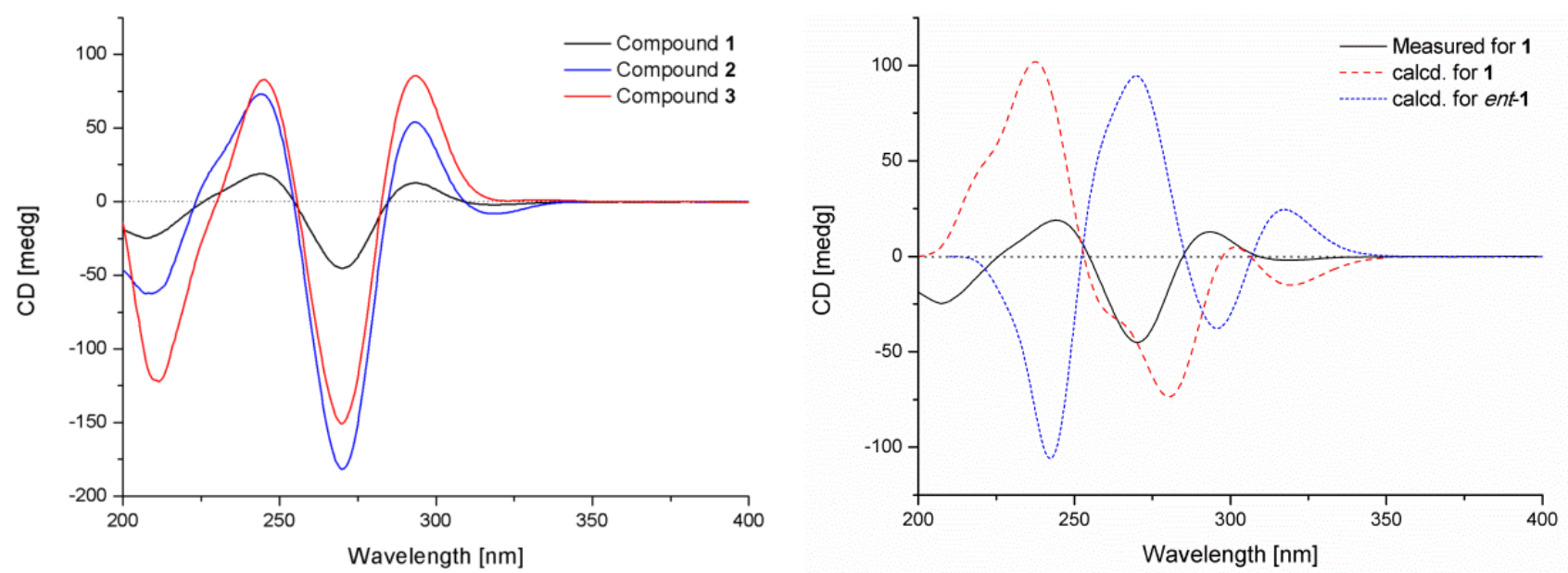

Figure 5. Measured CD curves of $\mathbf{1}-\mathbf{3}$ and calculated equivalent circulating density (ECD) curves of $\mathbf{1}$ and ent-1.

The absolute configuration at C-3" was determined using the modified Mosher's method [13]. Compound 1 esterified was separately with $(R)$-MTPA and $(S)$-MTPA chloride to give the $(S)$-MTPA and $(R)$-MTPA esters, $\mathbf{1 a}$ and $\mathbf{1 b}$, respectively. The distribution of $\Delta \delta$ values between $\mathbf{1 a}$ and $\mathbf{1 b}$ clearly defined the $S$-configuration at C-3" (Figure 6). Thus, the new Structure 1 was established as $\left(6 R, 7 R, 8 R, 9 S, 11 S, 21 R\right.$ and $\left.3^{\prime \prime} S\right)$.

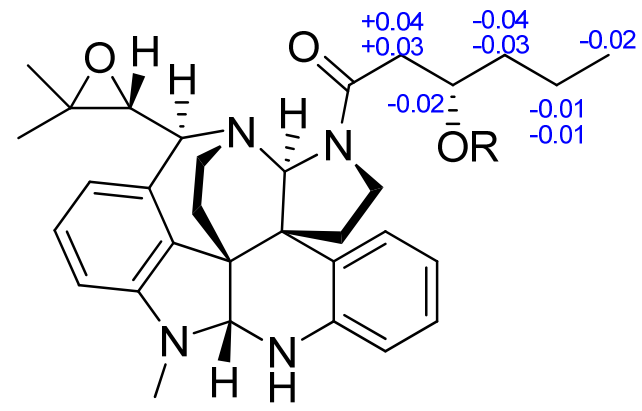

Figure 6. $\Delta \delta\left(=\delta_{S}-\delta_{R}\right)$ values for $(S)$ - and $(R)$-MTPA esters of 1 .

Fumiquinazoline Q (4) was obtained as a white amorphous powder. The molecular formula $\mathrm{C}_{23} \mathrm{H}_{21} \mathrm{~N}_{5} \mathrm{O}_{4}$ was assigned on the basis of the HRESIMS peak at $m / z 432.1673[\mathrm{M}+\mathrm{H}]^{+}$ (calcd. 432.1672), requiring 16 degrees of unsaturation. The IR absorption bands at 3436, 1685 and $1611 \mathrm{~cm}^{-1}$ of 4 suggested the presence of hydroxy and amido-carbonyl groups [14]. In the ${ }^{1} \mathrm{H}$ NMR spectrum, the signals for two ortho-disubstituted benzene ring system were present at $\delta_{\mathrm{H}} 7.63(1 \mathrm{H}, \mathrm{d}, J=8.0 \mathrm{~Hz}, \mathrm{H}-7) / \delta_{\mathrm{H}} 7.78(1 \mathrm{H}, \mathrm{t}, J=8.0 \mathrm{~Hz}, \mathrm{H}-8) / \delta_{\mathrm{H}} 7.50(1 \mathrm{H}, \mathrm{t}, J=8.0 \mathrm{~Hz}, \mathrm{H}-9) /$ $\delta_{\mathrm{H}} 8.30(1 \mathrm{H}, \mathrm{d}, J=8.0 \mathrm{~Hz}, \mathrm{H}-10)$ and $\delta_{\mathrm{H}} 7.52(1 \mathrm{H}, \mathrm{d}, J=7.4 \mathrm{~Hz}, \mathrm{H}-23) / \delta_{\mathrm{H}} 7.08(1 \mathrm{H}, \mathrm{t}, J=7.4 \mathrm{~Hz}$, $\mathrm{H}-24) / \delta_{\mathrm{H}} 7.30(1 \mathrm{H}, \mathrm{t}, J=7.4 \mathrm{~Hz}, \mathrm{H}-25) / \delta_{\mathrm{H}} 7.31(1 \mathrm{H}, \mathrm{d}, J=7.4 \mathrm{~Hz}, \mathrm{H}-26)$, which were further confirmed by COSY (Figure 2). The ${ }^{13} \mathrm{C}$ NMR data (Table 2) revealed the presence of 23 carbon signals, sorted by DEPT experiments into one methyl, two methylenes, eleven methines including eight aromatic methines, and nine quaternary carbons including two conjugated carbonyl groups $\left(\delta_{\mathrm{C}} 160.4, \mathrm{C}-12 ; 172.9, \mathrm{C}-20\right) .{ }^{1} \mathrm{H}$ and ${ }^{13} \mathrm{C}$ NMR (Table 2) spectra analysis revealed that 4 was an analogue of the known fumiquinazoline $\mathrm{A}$ [15], in which a methine $\left(\delta_{\mathrm{C} / \mathrm{H}} 49.2 / 4.88\right)$ was replaced by a 
methylene signal $\left(\delta_{\mathrm{C} / \mathrm{H}} 45.3 / 4.70,4.49\right)$ in 4 , whereas a methyl $\left(\delta_{\mathrm{C} / \mathrm{H}} 16.8 / 1.79\right)$ in fumiquinazolines $\mathrm{A}$ was absent. These data were further confirmed by the heteronuclear single quantum coherence (HSQC) of $\mathrm{H}_{\mathrm{a}-3}\left(\delta_{\mathrm{H}} 4.70\right)$ and $\mathrm{Hb}_{\mathrm{b}}-3\left(\delta_{\mathrm{H}} 4.49\right)$ to $\mathrm{C}-3\left(\delta_{\mathrm{C}} 45.3\right)$, the ${ }^{1} \mathrm{H}-{ }^{1} \mathrm{H}$ COSY of $\mathrm{Hb}_{\mathrm{b}}-3 / \mathrm{NH}-2$ $\left(\delta_{\mathrm{H}} 7.01\right)$ along with $\mathrm{HMBC}$ (Figure 2$)$ correlations from $\mathrm{H}_{2}-3\left(\delta_{\mathrm{H}} 4.70 / 4.49\right)$ to $\mathrm{C}-4\left(\delta_{\mathrm{C}} 148.0\right)$ and $\mathrm{C}-1$ ( $\delta_{\mathrm{C}}$ 169.9). Thus, the planar structure of 4 was established as shown in Figure 2. The relative configuration of 4 could be deduced from the NOESY data (Figure 3). The NOESY correlations of $\mathrm{H}_{\mathrm{a}}-15(\delta 2.37) / \mathrm{H}-17(\delta 5.25) / \mathrm{H}-19(\delta$ 4.25) suggested that $\mathrm{H}-17 / \mathrm{H}-19$ was in cis-configuration and $\mathrm{H}-17 / \mathrm{OH}-16$ was in trans-configuration. The absolute configuration at $\mathrm{C}-19$ was confirmed by acidic hydrolysis of 4, which afforded L-Ala that was determined by Marfey's method [16]. The absolute configuration at C-14 was also determined by ECD calculations of 4 and ent-4 [12]. The result showed that CD curve of $\mathbf{4}$ was consistent with the calculated ECD curve of $\mathbf{4}$ but opposite to that of ent-4 (Figure 7). Therefore, the absolute configuration of 4 was unambiguously assigned as (14R, 16R, $17 S, 19 S)$.

Table 2. ${ }^{1} \mathrm{H}$ and ${ }^{13} \mathrm{C}$ NMR Data of Compounds 4 and 5.

\begin{tabular}{|c|c|c|c|c|}
\hline \multirow{2}{*}{ Position } & \multicolumn{2}{|r|}{$4^{a}$} & \multicolumn{2}{|c|}{$5^{a}$} \\
\hline & $\boldsymbol{\delta}_{\mathrm{C}}$ & $\delta_{\mathrm{H}}$, Mult. $(J$ in $\mathrm{Hz})$ & $\boldsymbol{\delta}_{\mathrm{C}}$ & $\delta_{\mathrm{H}}$, Mult. $(J$ in $\mathrm{Hz})$ \\
\hline 1 & $169.9, \mathrm{C}$ & & $170.1, \mathrm{C}$ & \\
\hline 2 & & 7.01 , brs & & 8.26 , brs \\
\hline $3 a$ & $453 \mathrm{CH}$ & $4.70, \mathrm{~d}(15.6)$ & $662 \mathrm{CH}$ & $5.31, \mathrm{~d}(3.1)$ \\
\hline $3 b$ & $45.3, \mathrm{CH}_{2}$ & $4.49, \mathrm{~d}(15.6)$ & $66.2, \mathrm{CH}$ & \\
\hline 4 & $148.0, \mathrm{C}$ & & $146.8, \mathrm{C}$ & \\
\hline 6 & 147.1, C & & $146.4, \mathrm{C}$ & \\
\hline 7 & 127.1, CH & $7.63, \mathrm{~d}(8.0)$ & $127.8, \mathrm{CH}$ & $7.64, \mathrm{~d}(7.9)$ \\
\hline 8 & $135.1, \mathrm{CH}$ & $7.78, \mathrm{t}(8.0)$ & $135.3, \mathrm{CH}$ & $7.72, \mathrm{t}(7.9)$ \\
\hline 9 & $127.6, \mathrm{CH}$ & $7.50, \mathrm{t}(8.0)$ & $127.0, \mathrm{CH}$ & $7.45, \mathrm{t}(7.9)$ \\
\hline 10 & $127.3, \mathrm{CH}$ & $8.30, \mathrm{~d}(8.0)$ & $125.6, \mathrm{CH}$ & $8.18, \mathrm{~d}(7.9)$ \\
\hline 11 & $120.5, \mathrm{C}$ & & $120.5, \mathrm{C}$ & \\
\hline 12 & $160.4, \mathrm{C}$ & & $159.8, \mathrm{C}$ & \\
\hline 14 & $51.5, \mathrm{CH}$ & $5.81, \mathrm{dd}(8.6,3.8)$ & $54.1, \mathrm{CH}$ & $5.62, \mathrm{dd}(4.7,2.3)$ \\
\hline $15 \mathrm{a}$ & $307 \mathrm{CH}_{2}$ & $2.37, \mathrm{dd}(14.5,8.9)$ & $372 \mathrm{CH}_{2}$ & $2.49, \mathrm{dd}(15.3,2.1)$ \\
\hline $15 b$ & $39.1, \mathrm{CH}_{2}$ & $2.74, \mathrm{dd}(14.5,3.9)$ & $3 / .2, \mathrm{CH}_{2}$ & $3.28, \mathrm{dd}(15.3,5.1)$ \\
\hline 16 & $74.2, \mathrm{C}$ & & 74.8, C & \\
\hline 17 & 79.8, CH & $5.25, \mathrm{~s}$ & $80.9, \mathrm{CH}$ & $4.58, \mathrm{~d}(1.3)$ \\
\hline 19 & $59.0, \mathrm{CH}$ & $4.25, \mathrm{q}(12.8,6.2)$ & $64.3, \mathrm{CH}$ & $4.21, \mathrm{q}(11.9,6.5)$ \\
\hline 20 & $172.9, \mathrm{C}$ & & $165.8, \mathrm{C}$ & \\
\hline 22 & $137.4, \mathrm{C}$ & & 136.1, C & \\
\hline 23 & $115.8, \mathrm{CH}$ & $7.52, \mathrm{~d}(7.4)$ & $115.2, \mathrm{CH}$ & $7.39, \mathrm{~d}(7.6)$ \\
\hline 24 & $125.3, \mathrm{CH}$ & $7.08, \mathrm{t}(7.4)$ & $128.1, \mathrm{CH}$ & $7.24, \mathrm{t}(7.6)$ \\
\hline 25 & $130.3, \mathrm{CH}$ & $7.30, \mathrm{t}(7.4)$ & $130.5, \mathrm{CH}$ & $7.08, \mathrm{t}(7.6)$ \\
\hline 26 & $124.2, \mathrm{CH}$ & $7.31, \mathrm{~d}(7.4)$ & $124.4, \mathrm{CH}$ & $7.34, \mathrm{~d}(7.6)$ \\
\hline 27 & $138.0, \mathrm{C}$ & & 138.1, C & \\
\hline 28 & $18.2, \mathrm{CH}_{3}$ & $1.39, \mathrm{~d}(6.6)$ & $14.9, \mathrm{CH}_{3}$ & $1.51, \mathrm{~d}(6.5)$ \\
\hline $16-\mathrm{OH}$ & & 5.00, brs & & 4.64, brs \\
\hline
\end{tabular}

${ }^{\text {a }}$ Measured in $\mathrm{CDCl}_{3}\left({ }^{1} \mathrm{H} 600 \mathrm{MHz},{ }^{13} \mathrm{C} 150 \mathrm{MHz}, \mathrm{TMS}, \delta \mathrm{ppm}\right)$. 


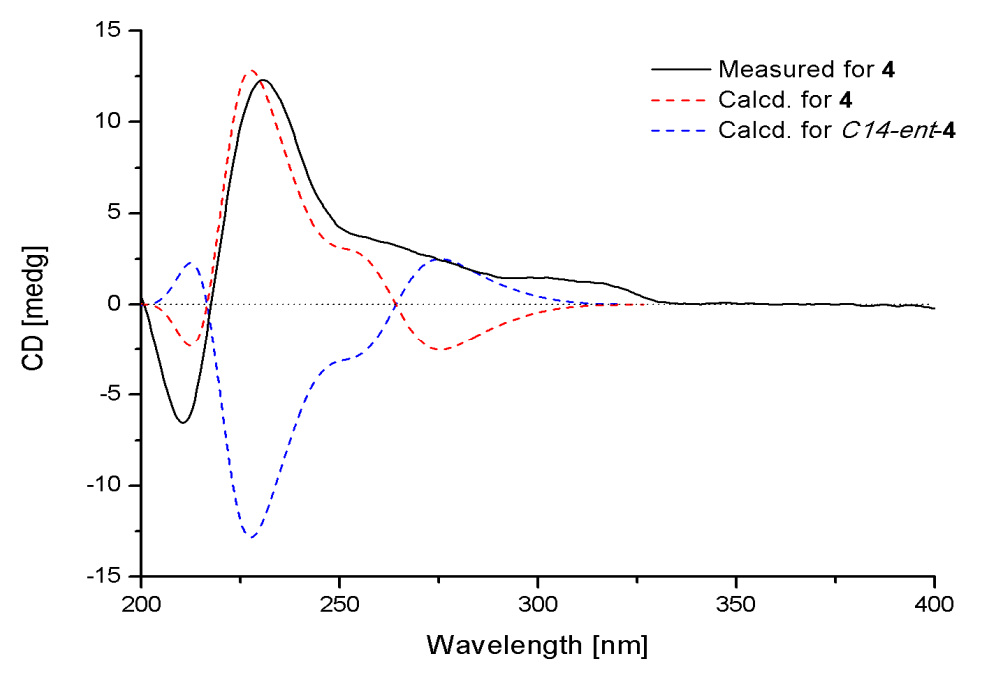

Figure 7. Measured and calculated ECD spectra for 4.

Protuboxepin E (8) was obtained as a white amorphous powder. The molecular formula of $\mathbf{8}$ was determined to be $\mathrm{C}_{22} \mathrm{H}_{23} \mathrm{~N}_{3} \mathrm{O}_{3}$ by analysis of ${ }^{1} \mathrm{H},{ }^{13} \mathrm{C}$ and DEPT NMR data and was verified by the HRESIMS peak at $m / z 378.1821[\mathrm{M}+\mathrm{H}]^{+}$(calcd. 378.1818), indicating 13 degrees of unsaturation. Its IR spectrum exhibited absorption at 3610,1679 and $1539 \mathrm{~cm}^{-1}$, characteristic of hydroxyl, amide and aromatic ring groups [17]. The ${ }^{1} \mathrm{H}$ NMR spectrum of $\mathbf{8}$ showed the signals for a 1,2,3-trisubstituted benzene ring system, and a monosubstituted benzene ring system was present at $\delta_{\mathrm{H}} 7.25(1 \mathrm{H}, \mathrm{d}, J=7.9 \mathrm{~Hz}, \mathrm{H}-9) / \delta_{\mathrm{H}} 7.37(1 \mathrm{H}, \mathrm{t}, J=7.9 \mathrm{~Hz}, \mathrm{H}-10) / \delta_{\mathrm{H}} 7.59(1 \mathrm{H}, \mathrm{d}, J=7.9 \mathrm{~Hz}, \mathrm{H}-11)$ and $\delta_{\mathrm{H}} 6.92(2 \mathrm{H}, \mathrm{d}, J=7.0 \mathrm{~Hz}, \mathrm{H}-17 / 21) / \delta_{\mathrm{H}} 7.20(2 \mathrm{H}, \mathrm{t}, J=7.0 \mathrm{~Hz}, \mathrm{H}-18 / 22) / \delta_{\mathrm{H}} 7.24(1 \mathrm{H}, \mathrm{m}, \mathrm{H}-19)$, which was further confirmed by COSY (Figure 2). The ${ }^{13} \mathrm{C}$ NMR data (Table 1) revealed the presence of 22 carbon signals, sorted by DEPT experiments into two methyls, two methylenes, eleven methines including eight aromatic methines, and seven quaternary carbons including two conjugated carbonyl groups $\left(\delta_{\mathrm{C}} 167.4, \mathrm{C}-2 ; 160.0, \mathrm{C}-13\right.$ ). The NMR data of 8 implied that it was an analogue of protuboxepin A [7], except for the obvious upfielded shift for C-7 and downfielded shifts for C-8 and $\mathrm{C}-12$ in 8. Meanwhile, C-9 in protuboxepin A had been transformed from a methine into a quaternary carbon in $\mathbf{8}$, which implied a replacement of the 7-membered ring $\mathrm{A}$ in protuboxepin $\mathrm{A}$ by a hexatomic benzene ring in $\mathbf{8}$ with the ether bond in protuboxepin A changed to a hydroxyl in $\mathbf{8}$. The ${ }^{1} \mathrm{H}-{ }^{1} \mathrm{H}$ COSY experiment exhibited correlations of $\mathrm{H}-4\left(\delta_{\mathrm{H}} 3.19\right) / \mathrm{H}-22\left(\delta_{\mathrm{H}} 2.69\right) / \mathrm{H}_{2}-24\left(\delta_{\mathrm{H}} 1.17\right) / \mathrm{H}_{3}-25\left(\delta_{\mathrm{H}} 0.73\right)$ (Figure 2), the HMBC experiment showed correlations from $\mathrm{H}-9\left(\delta_{\mathrm{H}} 7.25\right)$ to $\mathrm{C}-7\left(\delta_{\mathrm{C}} 135.7\right)$ and $\mathrm{C}-11$ $\left(\delta_{\mathrm{C}} 116.0\right), \mathrm{H}-10\left(\delta_{\mathrm{H}} 7.37\right)$ to $\mathrm{C}-8\left(\delta_{\mathrm{C}} 152.6\right)$ and $\mathrm{C}-12\left(\delta_{\mathrm{C}} 120.5\right), \mathrm{H}-11\left(\delta_{\mathrm{H}} 7.59\right)$ to $\mathrm{C}-7\left(\delta_{\mathrm{C}} 135.7\right)$, C-9 $\left(\delta_{\mathrm{C}} 118.7\right)$ and $\mathrm{C}-13\left(\delta_{\mathrm{C}} 160.0\right), \mathrm{H}_{3}-25$ to $\mathrm{C}-22\left(\delta_{\mathrm{C}} 35.0\right)$ and $\mathrm{H}_{2}-24$ to $\mathrm{C}-4\left(\delta_{\mathrm{C}} 57.8\right)$. These data further proved the planar construction of $\mathbf{8}$ shown in Figure 1. The observation of key NOESY correlations of $\mathrm{H}-4$ with $\mathrm{H}_{2}-15, \mathrm{H}-17$ and $\mathrm{H}-21$ indicated a trans-orientation of $\mathrm{H}-1 / \mathrm{H}-4$. In addition, Marfey's analysis of the acid hydrolysis of $\mathbf{8}$ afforded a D-phenylalanine residue. Therefore, the absolute configurations of C-1 and C-4 were determined as $R$ and $S$, respectively. Murata's $J$-based method and Marfey's analysis were applied to assign the absolute stereochemistry at C-22, but it was unfortunately unsuccessful because of the uncertainty of the single bond C4-C22, which could rotate freely. Thus, the configuration of C-22 has not been determined. 
The partial absolute stereostructure of the known Compound $\mathbf{5}$ was first determined by the Marfey's method [5]. According to the L-Ala residue in acidic hydrolysis of 5, the partial absolute stereostructure of 5 was unambiguously assigned as $(16 R, 17 S, 19 S)$.

Zebrafish embryos of the AB wild-type strain and TG (VEGFR2: GFP) type strain with fluorescent blood vessels were used to screen Compounds 1-12 for cardiovascular effects [18-20]. In the heart rate experiments, all of the compounds showed a significant mitigative effect on bradycardia caused by astemizole (ASM) at different concentrations (Figure 8). Figure 9 gives representative examples of the vasculogenetic effect observed in zebrafish by the test compounds. Regarding number of vessels, Compounds 4-6 and 8-12 (at concentrations of $20 \mu \mathrm{g} / \mathrm{mL}, 50 \mu \mathrm{g} / \mathrm{mL}$ and $100 \mu \mathrm{g} / \mathrm{mL}$ ) exhibited potent vasculogenetic activity and Compounds 1, 2 and 7 had moderate effects, while Compound 3 was ineffective. Regarding vessels length, four hits $(4,6,8$ and 10) displayed remarkable promoting function; mild effects were identified for Compounds 1, 2, 5, 7 and 11. Compounds 3, 9 and 12 did not show any relevant activity. As additional investigations aiming at screening for cardiovascular effects in the model of live zebrafish, 12 compounds were also evaluated in an antiangiogenic experiment, and no obvious activity was observed. This is the first report showing cardiovascular effects of these compounds in zebrafish.

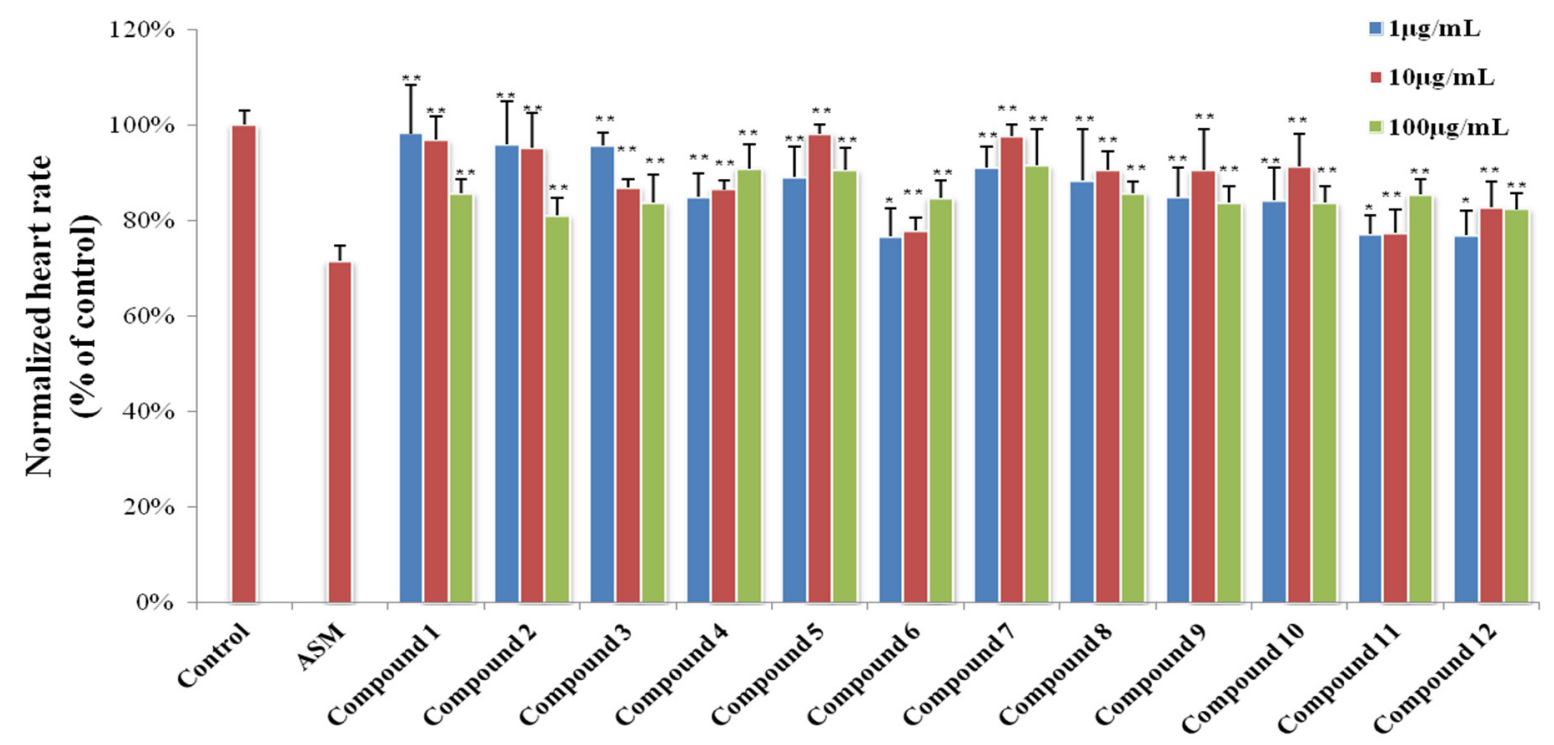

Figure 8. Results of zebrafish heart rate experiments. Significant difference between compound treatment and Astemizole (ASM) $(* p<0.05 ; * * p<0.01)$. The $1 \%$ DMSO-treated group is represented as "Control". 

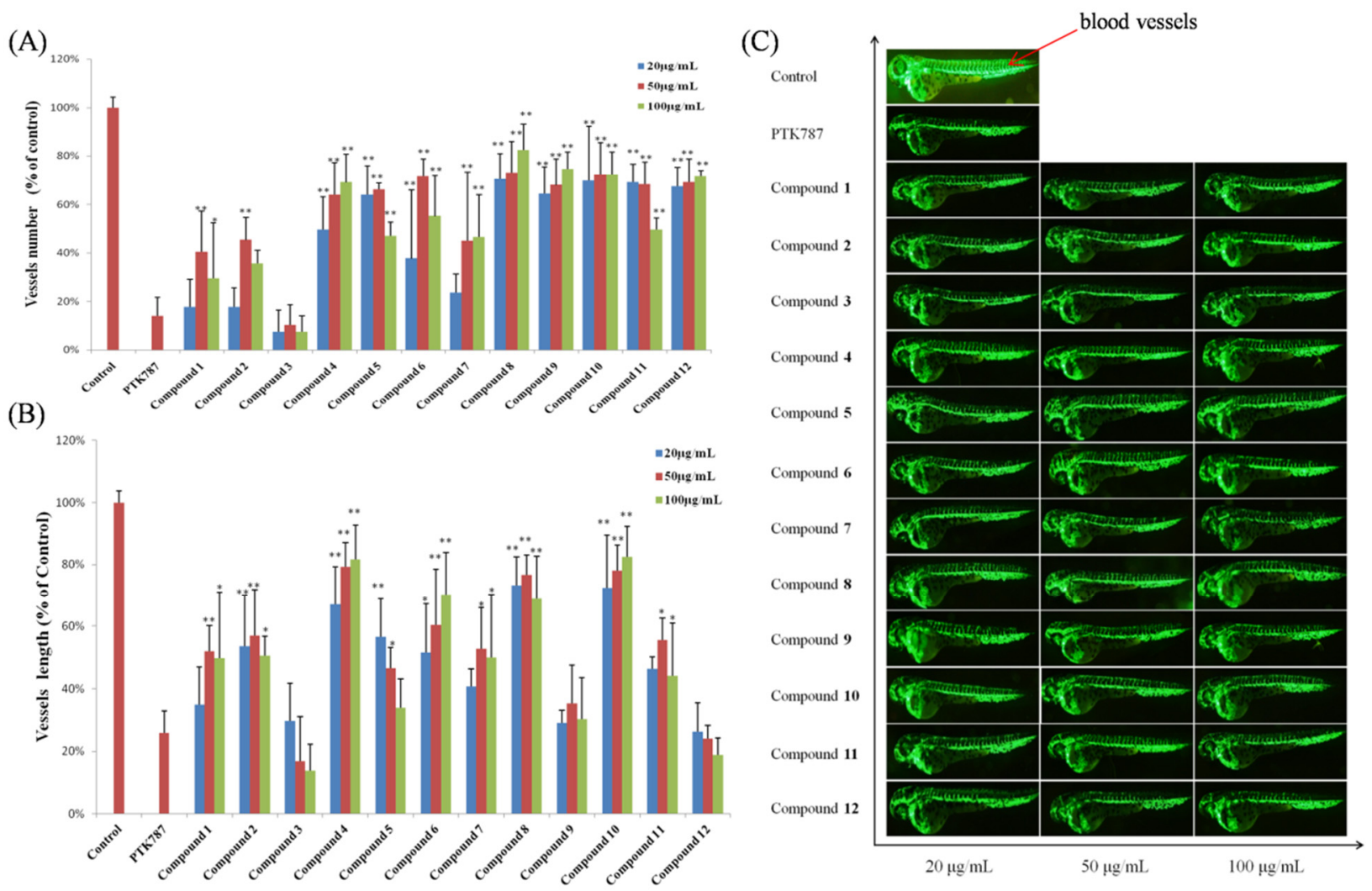

Figure 9. Results of vasculogenesis experiments. (A) Number of vessels in zebrafish treated with 12 compounds in the vasculogenesis experiments; (B) vessel length of zebrafish treated with 12 compounds in the vasculogenesis experiments; (C) representative images of zebrafish treated with 12 compounds in the vasculogenesis experiments (blood vessels are shown as red arrows). Significant difference between compound treatment and PTK787 (* $p<0.05 ; * * p<0.01)$. The $1 \%$ DMSO-treated group is represented as "Control".

\section{Experimental Section}

\subsection{General Experimental Procedures}

Optical rotations were measured on a Perkin-Elmer 341 digital polarimeter (Perkin-Elmer, Waltham, MA, USA). UV spectra were recorded on an eppendorf BioSpectrometer Basic photometer. IR spectra were obtained on a Nicolet Nexus 470 spectropolarimeter (Thermo Nicolet Analytical Instruments, Madison, WI, USA) as $\mathrm{KBr}$ discs. $\mathrm{CD}$ data were measured on a JASCO J-715 spectropolarimeter (Jasco, Tokyo, Japan). ${ }^{1} \mathrm{H}$ NMR, ${ }^{13} \mathrm{C}$ NMR, DEPT, HMQC, HMBC, COSY and NOESY spectra were recorded using a JEOL JNM-ECP 600 spectrometer (JEOL, Tokyo, Japan). HRESIMS spectra were measured on an Agilent Technologies G1969A mass spectrometer (Agilent Technologies Inc., Santa Clara, CA, USA). Analytical high performance liquid chromatography (HPLC) system (HITACHI, Tokyo, Japan) consisted of Organizer, UV Detector L-2400, Pump L-2130 and software Hitachi Model D-2000 Elite using a C18 column (YMC-pack ODS-A, $150 \times 4.6 \mathrm{~mm}, \mathrm{~S}-5 \mu \mathrm{M}$, $12 \mathrm{~nm}, 1 \mathrm{~mL} / \mathrm{min})$. Semipreparative HPLC was operated on the same system using a Prep RP-18 column (YMC-pack ODS-A, $250 \times 10 \mathrm{~mm}, \mathrm{~S}-5 \mu \mathrm{M}, 12 \mathrm{~nm}, 2.5 \mathrm{~mL} / \mathrm{min}$ ) with UV detection. Vacuum-liquid chromatography (VLC) used silica gel H (Qingdao Marine Chemical Factory, 
Qingdao, China). Thin layer chromatography (TLC) and column chromatography were performed on plates pre-coated with silica gel GF254 (10-40 $\mu \mathrm{m}$ ) and Sephadex LH-20 (Amersham Biosciences, Piscataway, NJ, USA), respectively.

\subsection{Fungal Material and Fermentation}

The fungus Penicillium expansum Y32 was originally obtained from a seawater sample collected

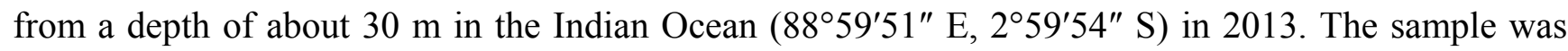
cultured in a Malt Extract Agar (MEA: Malt extract, $17 \mathrm{~g}$; Peptone, 3 g; Agar, 20 g; sea water, $1 \mathrm{~L})$ plate using chloramphenicol $(100 \mu \mathrm{g} / \mathrm{mL})$ as a bacterial inhibitor. A single colony was transferred onto another MEA plate and was identified according to its morphological characteristics and 18S rRNA gene sequences (GenBank access No. KP872504, supplementary materials). The fungus Penicillium expansum Y32 was cultured in $1000 \mathrm{~mL}$ conical flasks containing $300 \mathrm{~mL}$ fermentation media consisting of $1.7 \%$ malt extract and $0.3 \%$ peptone at $28{ }^{\circ} \mathrm{C}$ for 30 days.

\subsection{Extraction and Purification}

The whole fermentation broth $(15 \mathrm{~L})$ of cultivated medium was extracted exhaustively with EtOAc, while the mycelia were extracted with $80 \%$ volume aqueous acetone. After removing the acetone by evaporation under vacuum, the obtained aqueous acetone solution was extracted three times with EtOAc. The combined EtOAc extracts were dried under vacuum to produce $10.1 \mathrm{~g}$ of extract. The combined extract was subjected to silica gel chromatography using a vacuum liquid chromatography (VLC) column, eluting with a stepwise gradient of a mixture of petroleum ether (PE)- $\mathrm{CH}_{2} \mathrm{Cl}_{2}$ (2:1 and 0:1), then of $\mathrm{CH}_{2} \mathrm{Cl}_{2}-\mathrm{MeOH}(100: 1,50: 1,30: 1,10: 1,1: 1$, and 0:1) to yield eight major primary fractions (Fr.1-Fr.10). Fraction 6 was eluted with $\mathrm{CH}_{2} \mathrm{Cl}_{2}-\mathrm{MeOH}(100: 1)$ and was further resolved into four fractions (Fr.6.1-Fr.6.4) followed by reversed-phase $\mathrm{C} 18$ silica column chromatography eluting with a stepwise gradient of $30 \%$ to $100 \% \mathrm{MeOH}$ in $\mathrm{H}_{2} \mathrm{O}$. Fraction 3 (72 mg) was eluted with $\mathrm{CH}_{2} \mathrm{Cl}_{2}-\mathrm{MeOH}(60: 1)$ and was further resolved into four fractions (Fr.3.1-Fr.3.4) followed by reversed-phase $\mathrm{C} 18$ silica column chromatography $(30 \times 400 \mathrm{~mm})$ eluting with a stepwise gradient of $30 \%$ to $90 \% \mathrm{MeOH}$ in $\mathrm{H}_{2} \mathrm{O}$. Fraction $3.4(90 \% \mathrm{MeOH})$ was further purified by Sephadex LH-20 chromatography $(20 \times 1000 \mathrm{~mm})$ eluting with $\mathrm{MeOH}$ to obtain Fr. 3.4.1-Fr. 3.4.3. Fraction 3.4.1 was then further purified by semi-preparative HPLC over ODS $\left(70 \% \mathrm{MeOH}-\mathrm{H}_{2} \mathrm{O}, v / v\right)$ to give Compound $1\left(t_{\mathrm{R}}=23.3 \mathrm{~min} ; 1.7 \mathrm{mg}\right)$ and compound $2\left(t_{\mathrm{R}}=18.6 \mathrm{~min}, 11.3 \mathrm{mg}\right)$. Fraction $3.4 .2 \mathrm{was}$ subjected to HPLC over ODS $\left(70 \% \mathrm{MeOH}-\mathrm{H}_{2} \mathrm{O}, v / v\right)$ to yield Compound $3\left(t_{\mathrm{R}}=29.0 \mathrm{~min}, 30 \mathrm{mg}\right)$. Fraction 4 (123 mg) was subjected to reversed-phase C18 silica column chromatography $(30 \times 400 \mathrm{~mm})$ eluting with $\mathrm{CH}_{2} \mathrm{Cl}_{2} / \mathrm{MeOH}(10 \%-90 \%)$ to afford five subfractions (Fr.4.1-Fr.4.5). Fraction 4.3 was separated by Sephadex LH-20 eluting with $\mathrm{MeOH}$ to provide five subfractions (Fr.4.3.1-Fr.4.3.5). Compounds $4\left(t_{\mathrm{R}}=15.9 \mathrm{~min}, 1.8 \mathrm{mg}\right)$ and $5\left(t_{\mathrm{R}}=11.3 \mathrm{~min}, 7.1 \mathrm{mg}\right)$ were purified from Fr.4.3.2 and Fr.4.3.3 by semi-preparative HPLC eluting with $70 \%$ and $60 \% \mathrm{MeOH}-\mathrm{H}_{2} \mathrm{O}$, respectively. Fraction 4.4 was purified by HPLC on ODS $\left(70 \% \mathrm{MeOH}_{-} \mathrm{H}_{2} \mathrm{O}, v / v\right)$ to yield $6\left(t_{\mathrm{R}}=11.5 \mathrm{~min}, 1.1 \mathrm{mg}\right)$ and $7\left(t_{\mathrm{R}}=10.5 \mathrm{~min}, 5.1 \mathrm{mg}\right)$. Fraction $6(52 \mathrm{mg})$ was separated by Sephadex LH-20 column $(20 \times 1000 \mathrm{~mm})$, eluting with $\mathrm{MeOH}$, to afford three subfractions (Fr.6.1-Fr.6.3). Fraction 6.1 was further purified by HPLC over ODS $\left(70 \% \mathrm{MeOH}-\mathrm{H}_{2} \mathrm{O}, v / v\right)$ to afford $8\left(t_{\mathrm{R}}=13.8 \mathrm{~min}, 2.7 \mathrm{mg}\right)$ 
and $9\left(t_{\mathrm{R}}=15.9 \mathrm{~min}, 1.5 \mathrm{mg}\right)$. Compound $10\left(t_{\mathrm{R}} 10.4 \mathrm{~min}, 1.2 \mathrm{mg}\right)$ was crystallized from a $70 \%$ $\mathrm{MeOH}-\mathrm{H}_{2} \mathrm{O}$ solution of subfraction 6.3. Fraction $2(151 \mathrm{mg})$ was eluted with a stepwise gradient of $30 \%$ to $90 \% \mathrm{MeOH}$ in $\mathrm{H}_{2} \mathrm{O}$ by reversed-phase $\mathrm{C} 18$ silica column chromatography $(30 \times 400 \mathrm{~mm})$. Fraction $2.4(90 \% \mathrm{MeOH})$ was further purified by semi-preparative HPLC over ODS $\left(70 \% \mathrm{MeOH}-\mathrm{H}_{2} \mathrm{O}\right.$, $v / v)$ to give Compounds $11\left(t_{\mathrm{R}}=14.1 \mathrm{~min}, 5.97 \mathrm{mg}\right)$ and $12\left(t_{\mathrm{R}}=22.4 \mathrm{~min}, 48.3 \mathrm{mg}\right)$.

Communesin I (1): White amorphous powder; $[\alpha]_{\mathrm{D}}^{20}-59$ (c 0.1, MeOH); UV (MeOH) $\lambda_{\max } 206(2.16)$, 248 (2.39), 268 (2.32), 320 (1.86) nm; CD (c 0.1, MeOH) $\lambda_{\max }(\Delta \varepsilon) 208(-1.2), 244(+0.8)$, 270 (-1.5), $294(+0.9), 319(-0.1) \mathrm{nm}$; IR (KBr) $v_{\max }$ 3618, 2926, 1740, 1692, 1646, 1548, 1532, 1512, 1427, 1390, 1339, 1012, $754 \mathrm{~cm}^{-1} ;{ }^{1} \mathrm{H}$ and ${ }^{13} \mathrm{C}$ NMR data, see Table 1; HRESIMS $\mathrm{m} / z$ 529.3184 $[\mathrm{M}+\mathrm{H}]^{+}$(calcd for $\mathrm{C}_{32} \mathrm{H}_{41} \mathrm{~N}_{4} \mathrm{O}_{3}, 529.3179$ ).

Fumiquinazoline $Q$ (4): White amorphous powder; $[\alpha]_{\mathrm{D}}^{20}+50(c \quad 0.1, \mathrm{MeOH}) ; \mathrm{UV}(\mathrm{MeOH}) \lambda_{\max }$ 204 (2.49), 227 (2.36) and 304 (1.46) nm; CD (c 0.1, MeOH) $\lambda_{\max }(\Delta \varepsilon) 210(-0.4), 230(+0.7)$, $302(+0.1) \mathrm{nm}$; IR (KBr) $v_{\max } 3745,3436,2925,1685,1611,1480,1389,1339,1256,1025,769 \mathrm{~cm}^{-1}$; ${ }^{1} \mathrm{H}$ and ${ }^{13} \mathrm{C}$ NMR data, see Table 2; HRESIMS $m / z 432.1673[\mathrm{M}+\mathrm{H}]^{+}$(calcd for $\mathrm{C}_{23} \mathrm{H}_{22} \mathrm{~N}_{5} \mathrm{O}_{4}$, 432.1672).

Cottoquinazoline $A$ (5): White amorphous powder; $[\alpha]_{\mathrm{D}}^{20}+80(c \quad 0.1, \mathrm{MeOH}) ; \mathrm{UV}(\mathrm{MeOH}) \lambda \max$ 225 (2.32), 250 (1.33), $303(0.10) \mathrm{nm} ;{ }^{1} \mathrm{H}$ and ${ }^{13} \mathrm{C}$ NMR data, see Table 2; HRESIMS $\mathrm{m} / \mathrm{z}$ $430.1499[\mathrm{M}+\mathrm{H}]^{+}$(calcd for $\mathrm{C}_{23} \mathrm{H}_{20} \mathrm{~N}_{5} \mathrm{O}_{4}, 430.1510$ ).

Protuboxepin E (8): White amorphous powder; $[\alpha]_{\mathrm{D}}^{20}-57$ (c $\left.0.1, \mathrm{MeOH}\right) ; \mathrm{UV}(\mathrm{MeOH}) \lambda_{\max }$ 237 (2.63), 285 (2.16), $321(2.15) \mathrm{nm} ; \mathrm{CD}(c 0.1, \mathrm{MeOH}) \lambda_{\max }(\Delta \varepsilon) 238(-1.1), 326(-0.5) \mathrm{nm}$; IR (KBr) $v_{\max } 3672,3610,2968,1679,1539,1514,1456,1389,1215,762 \mathrm{~cm}^{-1} ;{ }^{1} \mathrm{H}$ and ${ }^{13} \mathrm{C}$ NMR data, see Table 1; HRESIMS $m / z$ 378.1821 [M+H] $]^{+}$calcd for $\mathrm{C}_{22} \mathrm{H}_{24} \mathrm{~N}_{3} \mathrm{O}_{3}, 378.1818$ ).

\subsection{Preparation of the (S)-and (R)-MTPA Esters of $\mathbf{1 a}$ and $\mathbf{1 b}$ by Modified Mosher's Method}

Compound 1 (1 mg for each) and 4-dimethylaminopyridine (1 mg) were dissolved with anhydrous $\mathrm{CH}_{2} \mathrm{Cl}_{2}(500 \mu \mathrm{L})$. Under $\mathrm{N}_{2}$ atmosphere, triethylamine $(20 \mu \mathrm{L})$ and $R-(-)$ - or $S-(+)-\mathrm{MTPA}$ chloride $(10 \mu \mathrm{L})$ were added. The reaction mixture was stirred at room temperature for $2 \mathrm{~h}$ and quenched with saturated aqueous sodium bicarbonate $(1 \mathrm{~mL})$. Extraction with $\mathrm{CH}_{2} \mathrm{Cl}_{2}(3 \times 5 \mathrm{~mL})$ was carried out. The organic layers combined and separated by semipreparative HPLC on ODS $\left(80 \% \mathrm{MeOH}-\mathrm{H}_{2} \mathrm{O}\right.$, $v / v)$ to afford the $S$-MTPA ester $\mathbf{1 a}\left(1.2 \mathrm{mg}, t_{\mathrm{R}}=10.2 \mathrm{~min}\right)$ and $R$-MTPA ester $\mathbf{1 b}(0.8 \mathrm{mg}$, $\left.t_{\mathrm{R}}=10.4 \mathrm{~min}\right)$, respectively.

Compound 1a: ${ }^{1} \mathrm{H}$ NMR $\left(\mathrm{CDCl}_{3}, 600 \mathrm{MHz}\right) \delta 6.98(\mathrm{t}, J=7.7 \mathrm{~Hz}, 1 \mathrm{H}, \mathrm{H}-3), 6.85(\mathrm{t}, J=7.7 \mathrm{~Hz}, 1 \mathrm{H}$, H-13), 6.77 (d, $J=7.7 \mathrm{~Hz}, 1 \mathrm{H}, \mathrm{H}-2), 6.66$ (d, $J=7.7 \mathrm{~Hz}, 1 \mathrm{H}, \mathrm{H}-4), 6.65$ (d, $J=7.7 \mathrm{~Hz}, 1 \mathrm{H}, \mathrm{H}-1$ ), 6.02 (d, $J=7.7 \mathrm{~Hz}, 1 \mathrm{H}, \mathrm{H}-12), 5.92$ (d, $J=7.7 \mathrm{~Hz}, 1 \mathrm{H}, \mathrm{H}-14), 5.74$ (m, 1H, H-3"), 5.06 (s, 1H, H-9), 4.70 (s, 1H, H-6), 4.04 (d, $J=8.9 \mathrm{~Hz}, 1 \mathrm{H}, \mathrm{H}-11), 3.84$ (dd, $\left.J=11.3,8.8 \mathrm{~Hz}, 1 \mathrm{H}, \mathrm{H}_{\mathrm{a}}-17\right), 3.41$ (d, $\left.J=16.6 \mathrm{~Hz}, 1 \mathrm{H}, \mathrm{H}_{\mathrm{a}}-2^{\prime \prime}\right), 3.39$ (dd, $\left.J=16.2,8.0 \mathrm{~Hz}, 1 \mathrm{H}, \mathrm{H}_{\mathrm{a}}-20\right), 3.24$ (dd, $\left.J=16.2,8.0 \mathrm{~Hz}, 1 \mathrm{H}, \mathrm{H}_{\mathrm{b}}-20\right)$, $2.93\left(\mathrm{dd}, J=11.4,8.6 \mathrm{~Hz}, 1 \mathrm{H}, \mathrm{H}-\mathrm{H}_{\mathrm{b}}-17\right), 2.85$ (s, 3H, H-1'), 2.83 (d, J=8.9 Hz, 1H, H-21), 2.75 (dd, $\left.J=16.6,5.5 \mathrm{~Hz}, 1 \mathrm{H}, \mathrm{Hb}_{\mathrm{b}} 2^{\prime \prime}\right), 2.71\left(\mathrm{dd}, J=13.0,7.0 \mathrm{~Hz}, 1 \mathrm{H}, \mathrm{H}_{\mathrm{a}}-18\right), 2.34(\mathrm{dt}, J=12.6,8.8 \mathrm{~Hz}, 1 \mathrm{H}$, $\left.\mathrm{H}_{\mathrm{a}}-19\right), 2.24$ (dt, $\left.J=12.5,8.6 \mathrm{~Hz}, 1 \mathrm{H}, \mathrm{H}_{\mathrm{b}}-19\right), 1.97$ (dd, $\left.J=13.1,6.9 \mathrm{~Hz}, 1 \mathrm{H}, \mathrm{H}_{\mathrm{b}}-18\right), 1.70(\mathrm{~m}, 1 \mathrm{H}$, $\left.\mathrm{H}_{\mathrm{a}}-4^{\prime \prime}\right), 1.68$ (m, 1H, $\left.\mathrm{H}_{\mathrm{b}}-4^{\prime \prime}\right), 1.44$ (s, 3H, $\left.\mathrm{H}_{3}-24\right), 1.35$ (s, 3H, $\left.\mathrm{H}_{3}-23\right), 1.30$ (m, 1H, $\left.\mathrm{H}_{\mathrm{a}}-5^{\prime \prime}\right), 1.25$ (m, $\left.1 \mathrm{H}, \mathrm{H}_{\mathrm{b}}-5^{\prime \prime}\right), 0.90$ (s, 3H, H3-6"); ESIMS $m / z$ 745.4 [M+ H] $]^{+}$. 
Compound 1b: ${ }^{1} \mathrm{H} \mathrm{NMR}\left(\mathrm{CDCl}_{3}, 600 \mathrm{MHz}\right) \delta 7.00(\mathrm{t}, J=7.6 \mathrm{~Hz}, 1 \mathrm{H}, \mathrm{H}-3), 6.88(\mathrm{t}, J=7.7 \mathrm{~Hz}, 1 \mathrm{H}$, H-13), 6.71 (d, $J=7.6 \mathrm{~Hz}, 1 \mathrm{H}, \mathrm{H}-2), 6.69$ (d, $J=7.6 \mathrm{~Hz}, 1 \mathrm{H}, \mathrm{H}-4), 6.66$ (d, $J=7.6 \mathrm{~Hz}, 1 \mathrm{H}, \mathrm{H}-1)$, 6.05 (d, $J=7.7 \mathrm{~Hz}, 1 \mathrm{H}, \mathrm{H}-12), 5.95$ (d, $J=7.7 \mathrm{~Hz}, 1 \mathrm{H}, \mathrm{H}-14), 5.76$ (m, 1H, H-3"), 5.05 (s, 1H, H-9), 4.69 (s, 1H, H-6), 4.03 (d, $J=8.8 \mathrm{~Hz}, 1 \mathrm{H}, \mathrm{H}-11), 3.90$ (dd, $\left.J=11.8,8.6 \mathrm{~Hz}, 1 \mathrm{H}, \mathrm{H}_{\mathrm{a}}-17\right), 3.42$ (m, $\left.\mathrm{Ha}_{\mathrm{a}}-20\right), 3.37$ (dd, $\left.J=16.3,6.0 \mathrm{~Hz}, 1 \mathrm{H}, \mathrm{Ha}_{\mathrm{a}} 2^{\prime \prime}\right), 3.27$ (m, 1H, Hb-20), 2.99 (dd, $J=11.7,8.6 \mathrm{~Hz}, 1 \mathrm{H}$, H- $\left.\mathrm{H}_{\mathrm{b}}-17\right), 2.84$ (s, 3H, H-1'), 2.83 (d, $\left.J=9.0 \mathrm{~Hz}, 1 \mathrm{H}, \mathrm{H}-21\right), 2.72$ (dd, $J=16.5,5.9 \mathrm{~Hz}, 1 \mathrm{H}, \mathrm{H}_{\mathrm{b}}-2^{\prime \prime}$ ), 2.69 (dd, $\left.J=13.1,7.1 \mathrm{~Hz}, 1 \mathrm{H}, \mathrm{H}_{\mathrm{a}}-18\right), 2.33$ (dd, $\left.J=12.0,8.7 \mathrm{~Hz}, 1 \mathrm{H}, \mathrm{H}_{\mathrm{a}}-19\right), 2.25$ (m, 1H, $\left.\mathrm{H}_{\mathrm{b}}-19\right)$ ), 1.97 (dd, $J=13.2,6.9 \mathrm{~Hz}, 1 \mathrm{H}, \mathrm{Hb}-18), 1.74$ (m, 1H, Ha-4"), 1.71 (m, 1H, Hb-4"), 1.41 (s, 3H, H3-24), 1.34 (s, 3H, H3-23), 1.31 (m, 1H, Ha-5"), 1.26 (m, 1H, Hb-5"), 0.92 (s, 3H, H3-6"); ESIMS m/z 745.4 [M + H].

\subsection{Marfey's Analysis}

A solution of Compound $4(0.5 \mathrm{mg}) /$ Compound $5(0.5 \mathrm{mg})$ in $6 \mathrm{M} \mathrm{HCl}(0.5 \mathrm{~mL})$ was heated at $110{ }^{\circ} \mathrm{C}$ for $19 \mathrm{~h}$. Then the solution was evaporated to dryness. The residue, L-Ala and D-Ala were dissolved in $\mathrm{H}_{2} \mathrm{O}(250 \mu \mathrm{L}$ each), respectively. One hundred microliters of each solution was treated with $100 \mu \mathrm{L}$ of $1 \%$ solution of L-FDAA in acetone followed by $1.0 \mathrm{M} \mathrm{NaHCO}_{3}(40 \mu \mathrm{L})$. The reaction mixture was incubated for $1 \mathrm{~h}$ at $45^{\circ} \mathrm{C}$ before being quenched by $1.0 \mathrm{M} \mathrm{HCl}(40 \mu \mathrm{L})$. The derivatives of the hydrolysates and standard amino acids were analyzed by HPLC column (YMC-pack ODS-A, $10 \times 250 \mathrm{~mm}, 5 \mu \mathrm{m}, 1 \mathrm{~mL} / \mathrm{min}$ ) at $30{ }^{\circ} \mathrm{C}$ using the following gradient program: solvent $\mathrm{A}$, water $+0.2 \%$ TFA; solvent B, MeCN; linear gradient: $0 \min 25 \% \mathrm{~B}, 40 \min 60 \% \mathrm{~B}, 45 \min 100 \% \mathrm{~B}$; UV detection at $340 \mathrm{~nm}$. HPLC analysis showed that the retention times for $L$-FDAA derivatives of hydrolysates of 4/5, standard L-Ala and standard D-Ala were 11.7, 11.7 and $14.3 \mathrm{~min}$, respectively (Figures S26 and S27).

Similarly, Compound 8, standard L-phenylalanine and D-phenylalanine were also derivatized with L-FDAA and analyzed by HPLC column. HPLC analysis revealed that acid hydrolysates of 8 displayed the same retention time $(24.1 \mathrm{~min})$ as the D-phenylalanine but was different from L-phenylalanine (21.8 min) (Figure S28).

\subsection{Bioassays}

\subsubsection{Zebrafish Embryos}

Zebrafish (Danio rerio) of the AB wild-type strain and TG (VEGFR2:GFP) type strain were maintained under a $14 \mathrm{~h}$ light/10 h dark cycle in an automatic circulating tank system and fed with artificial granular bait and fresh Artemia nauplii [21]. Adult mating pairs were placed in a breeding tank in the evening, and fertilized eggs were collected in the next morning $(9 \mathrm{~h})$. After disinfected, fertilized eggs raised in culture solution $\left(5.0 \mathrm{mM} \mathrm{NaCl}, 0.17 \mathrm{mM} \mathrm{KCl}, 0.4 \mathrm{mM} \mathrm{CaCl}_{2}\right.$, and $\left.0.16 \mathrm{mM} \mathrm{MgSO}_{4}\right)$ in a light-operated incubator at $28.0^{\circ} \mathrm{C} \pm 0.5^{\circ} \mathrm{C}[22]$.

\subsubsection{Heart Rate Experiments}

Zebrafish embryos cultured for $48 \mathrm{~h}$ were arrayed into 24-well microtiter plates (six to eight embryos and $1000 \mu \mathrm{L}$ culture solution per well). Each test compound was diluted with DMSO, and $1 \mu \mathrm{L}$ of the working stock was added to each well, resulting in a final screening concentration of 1 , 
10 and $100 \mu \mathrm{g} / \mathrm{mL}$, respectively. Then $2 \mu \mathrm{M}$ ASM was added to all model groups. Two micromols of ASM was used as positive control and $1 \%$ DMSO was tested as negative control. After $24 \mathrm{~h}$ incubation with test compounds, the heart rate of each zebrafish was recorded by the inverted microscope (XSJ-D) (Figure 8) [10].

\subsubsection{Vasculogenesis Experiments}

Egg membranes were removed from embryos by pronase E solution $(1.0 \mathrm{mg} / \mathrm{mL})$ (Shanghai, China) at $24 \mathrm{~h}$ post fertilization. Then zebrafish embryos were added to 24 -well microtiter plates (six to eight embryos per well) treated with 20,50 and $100 \mu \mathrm{g} / \mathrm{mL}$ of each test compound and $4 \mu \mathrm{g} / \mathrm{mL}$ of vatalanib (PTK787, Basel, Switzerland). The positive control was $4 \mu \mathrm{g} / \mathrm{mL}$ PTK787 and the negative control was $1 \%$ DMSO (Shanghai, China). Before arraying the plate, unhealthy or developmentally delayed embryos were removed by examination under a stereoscopic microscope. After $24 \mathrm{~h}$ incubation in a light-operated incubator at $28.0{ }^{\circ} \mathrm{C} \pm 0.5{ }^{\circ} \mathrm{C}$, the number and length of intersegmental vessels were captured using a fluorescent microscope (SZX16 Tokyo, Japan) or image acquisition systems (DP2-BSW, Tokyo, Japan) (Figure 9) [10].

\subsubsection{Antiangiogenic Vessel Growth Experiments}

Zebrafish embryos cultured for $24 \mathrm{~h}$ were placed in 24-well microtiter plates, with six to eight embryos and $1000 \mu \mathrm{L}$ culture solution per well. Embryos were exposed to the compound solutions at 1 , 10 and $100 \mu \mathrm{g} / \mathrm{mL}$. At $48 \mathrm{hpf}$ (hours post fertilization), the influence on antiangiogenic vessel growth of each zebrafish was observed using inverted microscope (XSJ-D, Chongqing, China) and an automated custom algorithm was used to quantify the number of angiogenic vessels in the zebrafish.

\section{Conclusions}

Three new alkaloids (1, 4 and 8), together with nine known analogues $(\mathbf{2}, \mathbf{3}, \mathbf{5}-\mathbf{7}$, and 9-12), were isolated from the marine-derived fungus Penicillium expansum Y32. Their structures including the absolute configurations were elucidated by spectroscopic and Mosher's and Marfey's methods, along with quantum ECD calculations. Each of the compounds was evaluated for cardiovascular effects with live a zebrafish model. All of the compounds showed significant mitigative effects on bradycardia caused by astemizole (ASM) in the heart rate experiments. Compounds 4-6 and 8-12 exhibited potent vasculogenetic activity in the vasculogenesis experiments. The results suggested that these compounds could be promising candidates for cardiovascular disease lead compounds.

\section{Acknowledgments}

This work was supported by the National Basic Research Program of China (2015CB755906), the Hi-Tech Research and Development Program of China (2013AA092901-2), the China Ocean Mineral Resources Research and Development Association (DY125-15-T-07), the Public Welfare Project of SOA (201205027) and the Basic Scientific Fund for National Public Research Institutes of China (GY0213G12). Thanks go to the Research and Development Platform for Drug Screening of the Shandong Academy of Sciences for helping with all zebrafish experiments. 


\section{Author Contributions}

Ya-Qin Fan performed isolation and structure determination of the compounds and wrote the manuscript. Pei-Hai Li performed the fermentation of the fungus, extraction of the culture broths and isolation of the compounds. Ya-Xi Chao carried out the isolation and taxonomic identification of the fungus and performed the bioassays. Hao Chen designed the study and revised the manuscript. Ning Du collected the sea world sample from the Indian Ocean. Qiu-Xia He and Ke-Chun Liu designed and supervised the bioassays.

\section{Conflicts of Interest}

The authors declare no conflict of interest.

\section{References}

1. World Health Organization. Cardiovascular diseases (CVDs). Available online: http://www.who.int/mediacentre/factsheets/fs317/en/ (accessed on 27 September 2015).

2. Hideo, H.; Hirotaka, M.; Kohki, A. New insecticidal compounds, communesins C, D and E, from Penicillium expansum link MK-57. Biosci. Biotechnol. Biochem. 2004, 68, 753-756.

3. Dalsgaard, P.W.; Blunt, J.W.; Munro, M.H.G.; Frisvad, J.C.; Christophersen, C. Communesins G and $\mathrm{H}$, new alkaloids from the psychrotolerant fungus Penicillium rivulum. J. Nat. Prod. 2005, 68, $258-261$.

4. Zuo, Z.W.; Ma, D. Enantioselective Total Syntheses of Communesins A and B. Angew. Chem. Int. Ed. 2011, 50, 12008-12011.

5. Fremlin, L.J.; Piggott, A.M.; Lacey, E.; Capon, R.J. Cottoquinazoline A and Cotteslosins A and B, metabolites from an Australian marine-derived strain of Aspergillus versicolor. J. Nat. Prod. 2009, 72, 666-670.

6. Peng, J.X.; Lin, T.; Wang, W.; Xin, Z.H.; Zhu, T.J.; Gu, Q.Q.; Li, D.H. Antiviral alkaloids produced by the mangrove-derived fungus Cladosporium sp. PJX-41. J. Nat. Prod. 2013, 76, 1133-1140.

7. Lee, S.U.; Asami, Y.; Lee, D.; Jang, J.H.; Ahn, J.S.; Oh, H. Protuboxepins A and B and protubonines A and B from the marine-derived fungus Aspergillus sp. SF-5044. J. Nat. Prod. 2011, 74, 1284-1287.

8. Oikawa, H.; Murakami, Y.; Ichihara, A. 20-Ketoreductase Activity of Chaetoglobosin A and prochaetoglobosins in a cell-free system of chaetomium subaffine and the isolation of new chaetoglobosins. Biosci. Biotech. Biochem. 1993, 57, 628-631.

9. Iwamoto, C.; Yamada, T.; Ito, Y.; Minoura, K.; Numata, A. Cytotoxic cytochalasans from a Penicillium species separated from a marine alga. Tetrahedron 2001, 57, 2997-3004.

10. Tran, T.C.; Sneed, B.; Haider, J.; Blavo, D.; White, A.; Aiyejorun, T.; Baranowski, T.C.; Rubinstein, A.L.; Doan, T.N.; Dingledine, R.; et al. Automated, quantitative screening assay for antiangiogenic compounds using transgenic zebrafish. Cancer Res. 2007, 67, 11386-11392. 
11. Matsumori, N.; Kaneno, D.; Murata, M.; Nakamura, H.; Tachibana, K. Stereochemical determination of acyclic structures based on carbon-proton spin-coupling constants. A method of configuration analysis for natural products. J. Org. Chem. 1999, 64, 866-876.

12. Frisch, M.J.; Trucks, G.W.; Schlegel, H.B.; Scuseria, G.E.; Robb, M.A.; Cheeseman, J.R.; Montgomery, J.A., Jr.; Vreven, T.; Kudin, K.N.; Burant, J.C.; et al. Gaussian 03, Revision E.01; Gaussian, Inc.: Wallingford, CT, USA, 2004.

13. Ueoka, R.; Nakao, Y.; Kawatsu, S.; Yaegashi, J.; Matsumoto, Y.; Matsunaga, S.; Furihata, K.; van Soest, R.W.; Fusetani, N. Gracilioethers A-C, antimalarial metabolites from the marine sponge Agelas gracilis. J. Org. Chem. 2009, 74, 4203-4207.

14. Zhuang, Y.B.; Teng, X.C.; Wang, Y.; Liu, P.P.; Li, G.Q.; Zhu, W.M. New quinazolinone alkaloids within rare amino acid residue from coral-associated fungus, Aspergillus versicolor LCJ-5-4. Org. Lett. 2011, 13, 1130-1133.

15. Takahashi, C.; Matsushita, T.; Doi, M.; Minoura, K.; Shingu, T.; Kumeda, Y.; Numata, A. Fumiquinazolines A-G, novel metabolites of a fungus separated from a Pseudolabrus marine fish. J. Chem. Soc. Perkin Trans. 1995, 1, 2345-2353.

16. Marfey, P. Determination of D-amino acids. II. Use of a bifunctional reagent, 1,5-difluoro-2,4dinitrobenzene. Carlsberg Res. Commum. 1984, 49, 591-596.

17. Li, G.Y.; Li, L.M.; Yang, T.; Chen, X.Z.; Fang, D.M.; Zhang, G.L. Four new alkaloids, brevianamides $\mathrm{O}-\mathrm{R}$, from the fungus Aspergillus versicolor. Helv. Chim. Acta 2010, 93, 2075-2080.

18. Chan, J.; Bayliss, P.E.; Wood, J.M.; Roberts, T.M. Dissection of angiogenic signaling in zebrafish using a chemical genetic approach. Cancer Cell 2002, 1, 257-267.

19. Cross, L.M.; Cook, M.A.; Lin, S.; Chen, J.N.; Rubinstein, A.L. Rapid analysis of angiogenesis drugs in a live fluorescent zebrafish assay. Arterioscler. Thromb. Vasc. Biol. 2003, 23, 911-912.

20. Seng, W.L.; Eng, K.; Lee, J.; McGrath, P. Use of a monoclonal antibody specific for activated endothelial cells to quantitate angiogenesis in vivo in zebrafish after drug treatment. Angiogenesis 2004, 7, 243-253.

21. Han, Y.; Zhang, J.P.; Qian, J.Q.; Hu, C.Q. Cardiotoxicity evaluation of anthracyclines in zebrafish (Danio rerio). J. Appl. Toxicol. 2015, 35, 241-252.

22. McKinley, E.T.; Baranowski, T.C.; Blavo, D.O.; Cato, C.; Doan, T.N.; Rubinstein, A.L. Neuroprotection of MPTP-induced toxicity in zebrafish dopaminergic neurons. Mol. Brain Res. 2005, 141, 128-137.

(C) 2015 by the authors; licensee MDPI, Basel, Switzerland. This article is an open access article distributed under the terms and conditions of the Creative Commons Attribution license (http://creativecommons.org/licenses/by/4.0/). 